\title{
Do We Need Asymmetric Organocatalysis?
}

\author{
Peter I. Dalko*
}

\begin{abstract}
Asymmetric organocatalysis is a 'fast lane' of the chemical highway: the progress in the last decade is simply spectacular. This introductory article summarizes basic principles, historical background, and discusses basic catalyst classes and reaction types.
\end{abstract}

Keywords: Asymmetric synthesis · Bifunctional catalysts · Catalysis· History

Asymmetric synthesis, the ability to control the three-dimensional structure of the molecular architecture, has revolutionized chemistry in the second half of the XXth century. Amongst the various ways of creating enantiomerically enriched products, catalytic methods (i.e. when chemical transformations are controlled by a small amount of chiral compounds) are considered to be the most appealing. It is difficult to conceive that the impressive knowledge accumulated in this field was gained in a relatively short period of time. New concepts and methods are emerging continuously, allowing more selective, economically more appealing and environmentally friendlier transformations. In this context, asymmetric organocatalysis is a 'fast lane' of the chemical highway: the progress in the last decade is simply spectacular.
Performing chemical transformations with a small number of organic molecules that do not contain metal elements is not a novel concept: enantioselective organocatalytic transformations were developed prior to organometallic ones. The relatively narrow scope of these transformations, however, did not stir particular interest in the past. Nowadays the situation is changing. The renewed interest is due to the serendipitous discovery of a number of selective transformations and also to the realization of the tremendous potential which is inherent to these novel forms of activations, which are also complementary to the existing ones. ${ }^{[1-13]}$ The operational simplicity, ready availability of these mostly inexpensive bench-stable catalysts, which are incomparably more robust than enzymes or other bioorganic catalysts makes organocatalysis an attractive method for the synthesis of complex structures. In contrast to any other system developed earlier, organocatalytic reactions provide a rich platform for multicomponent, tandem, or domino-type multisteps reactions, ${ }^{[14]}$ allowing the increase of the structural complexity of the product in a highly stereocontrolled manner. There are usually fewer toxicity issues associated with organocatalysis although this only applies when dealing with the more notorious metals and it should be pointed out that little is known about the toxicity of many of the organic catalysts. Moreover there is no risk of metal leakage and also no expensive recovery process is required in the waste treatment. There are more and more industrial applications based on asymmetric organocatalytic reactions. The environmentally friendly, green aspect of this chemistry, coupled with the sustainability of the catalysts is more and more often considered when replacing standard metal-based reactions. ${ }^{[15,16]}$

\section{Historical Background}

The history of organocatalytic reactions looks back on a rich past. Evidence was found that this type of catalysis has played a determinant role in the formation of prebiotic key building blocks such as sugars, and allowed thus the introduction and widespreading of the homochirality in the living word.[17] Enantiomerically enriched amino acids such as L-alanine and L-isovaline, which may be present in up to $15 \%$ $e e$ in carbonaceous meteorites, would catalyze the dimerization of glycolaldehyde, and the reaction between glycolaldehyde and formaldehyde in an aldol-type reaction to afford sugar derivatives. Pizzarello and Weber demonstrated that L-isovaline, which was found in the Murchison meteorite, promotes the self-aldol reaction of glycolaldehyde in water, generating aldol products such as L-threose and D-erithrose with up to $10.7 \pm 1.2 \%$ and $4.8 \pm 0.9 e e$, respectively. ${ }^{[17]}$ Proline, the most efficient natural amino acid catalyst in aldol-type condensations is scarcely present in meteorites. Asymmetric photolysis in interstellar clouds may produce optically active proline, however, indicating that proline may have been transported to earth also. ${ }^{[18]}$ The formation of sugars under prebiotic conditions was amplified in a number of elegant de novo constructions of complex, differentiated carbohydrates by chemical synthesis. ${ }^{[19]}$ It is likely that these aldol products were the precursor of complex molecules such as RNA and DNA. Prebiotic RNA played probably a central role in orchestrating a number of key biochemical transformations necessary for life, in which sugars served as chiral templates. ${ }^{[20]}$ For example, it is considered that amino acid homochirality in proteins was determined 
during asymmetric aminoacylation, which is the first step in protein synthesis and thus was critical for the transition from the putative RNA world to the theater of proteins. ${ }^{[21]}$ According to this concept, the selectivity (L or $\mathrm{D}$ ) of the amino acids was determined in large part by the preestablished homochirality of RNA.

Organic molecules have been used as catalysts from the early age of synthetic chemistry. The discovery of the first organocatalytic reaction is attributed to $\mathrm{J}$. von Liebig. He found accidentally that dicyan is transformed into oxamide in the presence of an aqueous solution of acetaldehyde (Scheme 1). This efficient reaction found later industrial application as the basis of the Degussa oxamide synthesis.

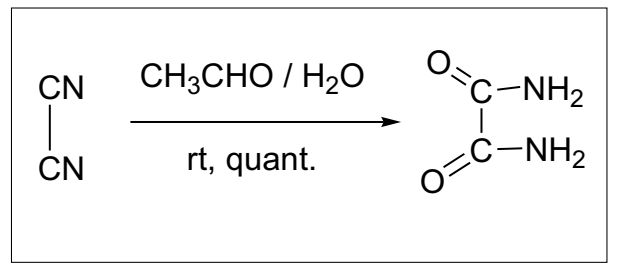

Scheme 1. von Liebig's oxamide synthesis

Undoubtedly, the discovery of enzymes and enzyme functions had an important impact on the development of asymmetric catalytic reactions. The first asymmetric reaction was a decarboxylative kinetic resolution, discovered by Pasteur. ${ }^{[22]} \mathrm{He}$ observed that the organism Penicillium glauca destroyed more rapidly one of the enantiomer $(d)$ from a racemic solution of ammonium tartarate. Asymmetric decarboxylation reactions were re-examined under non-enzymatic conditions by Georg Bredig in the beginning of the 1900s. At this time Bredig, who was certainly influenced by the wakening field of enzymology, was motivated to find the chemical origin of the enzyme activity. In his early experiments optically active camphor carboxylic acid was decarboxylated in $d$ - and $l$-limonenes, respectively. ${ }^{[23]}$ As an extension of this work he studied the decarboxylation of camphorcarboxylic acid catalyzed by nicotine, or quinidine and in the wake of these studies he established the basic equations of kinetic resolution. ${ }^{[24]}$ Not only decarboxylation reactions, but also $\mathrm{C}-\mathrm{C}$ bond forming reactions were discovered by Bredig. As much as the decarboxylation reaction, his seminal work on asymmetric cyanohydrin formation was also inspired by enzymatic transformation, and relied on Rosenthaler's earlier work on the formation of mandelonitrile by addition of $\mathrm{HCN}$ to benzaldehyde in the presence of an isolated enzyme, emulsin. ${ }^{[25]}$ Bredig was able to perform this reaction in the presence of the pseudoenantiomeric quinine and quinidine as catalysts (Scheme 2). ${ }^{[26]}$ While this work was conceptually

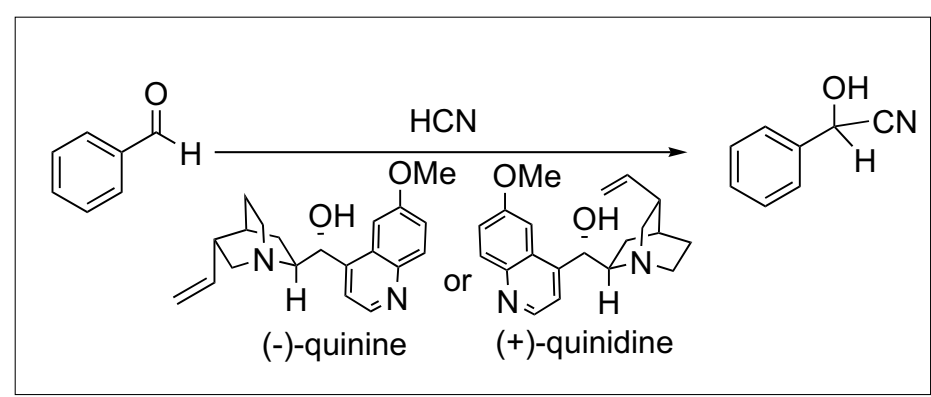

Scheme 2. Cinchona-mediated cyanohydrin synthesis

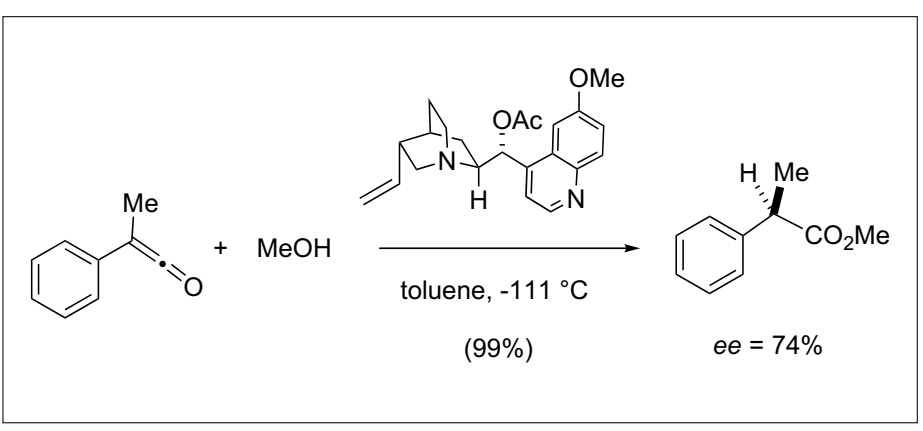

Scheme 3. Pracejus's enantioselective ester synthesis from phenyl ketene

groundbreaking, the enantioselectivity of the reaction was less then $10 \%$.

Although catalytic transformations gained more and more importance after the Great War, asymmetric reactions were considered an academic curiosity. It is noteworthy that the determination of the enantioselectivity was hampered by the lack of efficient purification and reliable analytical methods. The presence of chiral impurity arising often from the catalyst spoiled the determination of the correct, optical rotation-based $e e$ values.

$\mathrm{N}$-Containing natural products, such as alkaloids, in particular strychnine, brucine and cinchona alkaloids, and also amino acids including short oligopeptides were among the first organic catalysts tested. The acylating kinetic resolution of racemic secondary alcohols was initiated in the late 1920s by Vavon and Peignier in France, ${ }^{[27]}$ and, independently, by Wegler in Germany. ${ }^{[28]}$ They showed that brucine and strychnine were able to induce enantiomeric enrichment either in esterification of meso dicarboxylic acids or in the kinetic resolution of secondary alcohols, in low ee, however.

Catalytic synthetic methods attracted more interest between the two wars, and in the post-WWII period, ${ }^{[29]}$ and organocatalytic reactions were no exception. In particular Wolfgang Langenbeck's contribution on the use of amino acids and small peptides as catalysts should be remembered. Not surprisingly, enamine-type reactions were among the first to be discovered. This chemistry is rooted in Dakin's work, who noted as early as 1909 that amino acids may mediate efficiently the Knoevenagel-type condensation between aldehydes and carboxylic acids or esters having active methylene groups. ${ }^{[30]}$ The reaction was extended to aldol and related transformations, and was systematically studied from the early 30 s onwards with notable success, essentially with non-asymmetric systems.

The reinvestigation of Bredig's asymmetric cyanohydrine synthesis by Prelog in the mid $50 s^{[31]}$ promoted undoubtedly the concept of asymmetric synthesis, and paved the way for more efficient reactions. The advent of synthetically useful levels of enantioselectivity can be dated to the late 50s when Pracejus reported that methyl phenyl ketene can be converted to (-)- $\alpha$ phenyl methylpropionate in $74 \%$ ee using O-acetylquinine as catalyst (Scheme 3). ${ }^{[32]}$

This quite impressive result inspired the reinvestigation of other possible reaction manifolds for the cinchona catalyst system. Bergson and Långström reported the first Michael addition of $\beta$-keto esters to acrolein using 2-(hydroxymethyl)-quinuclidine as catalyst.[33] Although they never determined the enantiomeric excess they noted the optical activity of their products. Wynberg and co-workers carried out extensive studies of the use of cinchona alkaloids as chiral Lewis-base/nucleophilic catalysts. ${ }^{[34]}$ They showed that this class of alkaloid function as versatile catalysts, promoting a variety of 1,2- and 1,4-additions of a wide range of nucleophiles to carbonyl compounds. Noteworthy, in these early studies it was often observed that natural cinchona alkaloids were superior, in terms of both catalytic activity and selectivity to modified cinchona alkaloids derived from 


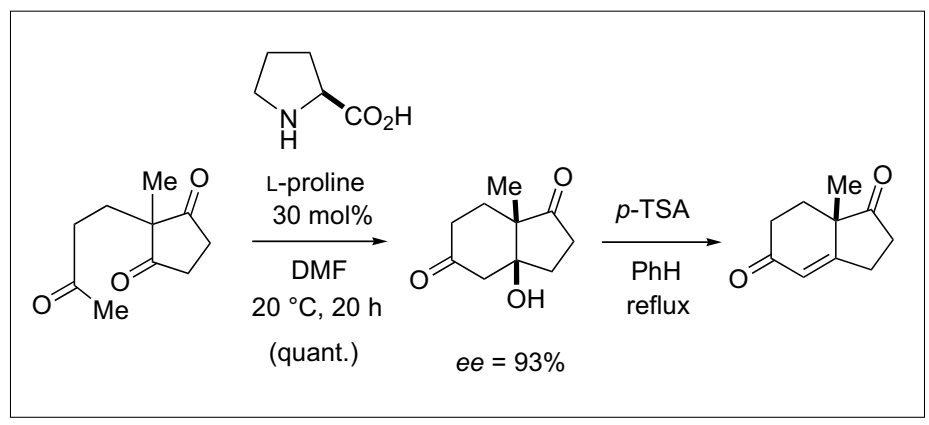

Scheme 4. The L-proline mediated Robinson annulation

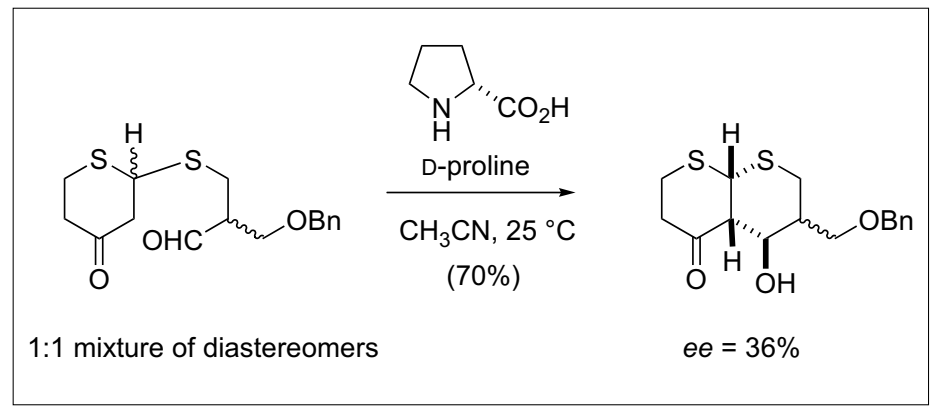

Scheme 5. The D-proline-mediated intramolecular aldol reaction in Woodward's erythromycin synthesis

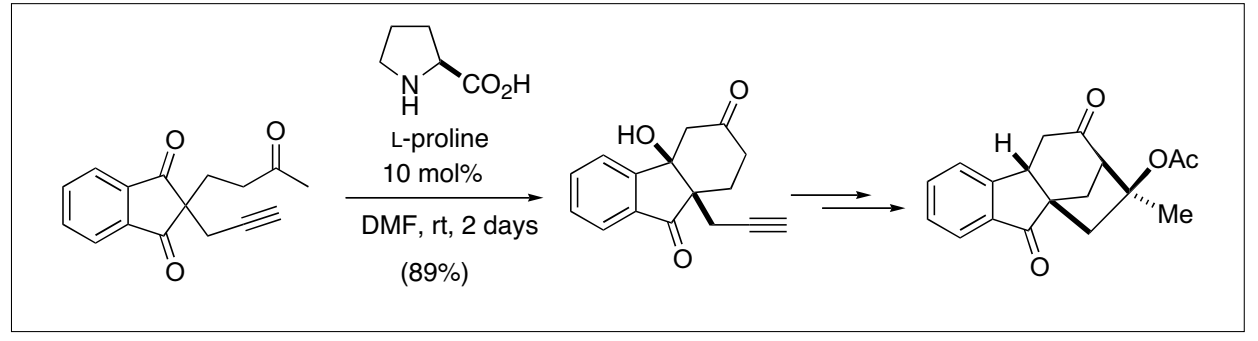

Scheme 6. Takano's gibbane synthesis

modification of the C-9 hydroxyl group. To rationalize this phenomenon, Wynberg proposed that the natural cinchona alkaloids are bifunctional catalysts utilizing both the tertiary amine and the hydroxyl group to activate and orient the nucleophile and electrophile, respectively, thus achieving optimum asymmetric catalysis. ${ }^{[34]}$

Another key event in the history of organocatalytic reaction was the discovery of efficient L-proline [ $(S)$-proline] mediated asymmetric Robinson annulation reported in the early 1970s. The so-called HajosParrish-Eder-Sauer-Wiechert reaction, an intramolecular aldol reaction, allowed access to some of key intermediates for the synthesis of natural products (Scheme 4), ${ }^{[35,36]}$ and offered a practical and enantioselective route to the Wieland-Miescher ketone. ${ }^{[37]}$ It is pertinent to note that this chemistry is rooted in the early studies of Langenbeck, and also in the extensive work of Stork and co-workers on enamine chemistry. ${ }^{[38]}$

This L-proline mediated annulation received considerable synthetic and mechanistic interest. ${ }^{[39]}$ The reaction was also used to prepare some 19 norsteroides on an industrial scale. ${ }^{[40]}$ It was demonstrated that other amino acids, such as $(R)$-phenylalanine could replace in some cases advantageously L-proline. ${ }^{[41]}$ Earlier applications in total syntheses appeared, however, as singular events, as it was in Woodward's erythromycin synthesis (Scheme 5). ${ }^{[42 a]}$ Remarkably, in this synthesis a racemic keto aldehyde could be used for aldolization with D-proline catalyst. All of the chiral centers of the erythronolide backbone directly or indirectly come from this rather poor reaction, which was only of $36 \%$ ee. However an optically pure down- stream product was separated by simple recrystallization, which made the process eminently practical.

The asymmetric construction of the gibbane framework by Takano et al. was also realized by the L-proline mediated intramolecular aldol reaction (Scheme 6). ${ }^{[42 \mathrm{~b}]}$

The late 70s and early 80s marked definitively a turning point, and the advent of more general efficient asymmetric organocatalysts, and also of organocatalytic reactions. A number of reactions proceeding via ion-pairing mechanisms (i.e. similar to that noted for cinchona alkaloids) were discovered. Chiral diketopiperazines were developed as chiral Brønsted acids for asymmetric hydrocyanation reactions by Mori and Inoue. ${ }^{[43]}$ This reaction paved the way of the efficient hydrocyanation reactions of aldimines developed some years later by the groups of Lipton and Jacobsen. ${ }^{[44,45]}$

The advent of efficient phase-transfer reactions dates back to the mid 80s, when researchers at Merck reported that substituted 2-phenyl-1-indanone systems could be alkylated with remarkably high enantioselectivity (up to 94\%) in the presence of catalytic amounts of substituted N-benzylcinchoninium halides $\left(50 \% \mathrm{NaOH} /\right.$ toluene). ${ }^{[46]}$ The reaction was reinvestigated by O'Donnell et al. who developed a general methodology for the alkylation of $t$-butylglycine imine giving flexible access either to the $\mathrm{D}$ or, to the $\mathrm{L}$ series of amino acids, respectively, depending on the pseudoenantiomeric cinchona alkaloid used. ${ }^{[47]}$ It was realized, however, only years later, that "the active catalysts in the asymmetric PTC alkylation is the N-alkyl$\mathrm{O}$-alkyl cinchona salt which is formed in situ during the reaction". ${ }^{[48]}$
The chiral amine-mediated cycloaddition reactions, pioneered by Kagan, ${ }^{[49]}$ and also the earliest examples of the enantioselective oxidation of chalcones using polyamino- or resin-bonded polyamino acid under tri- and biphasic conditions, the so-called Julià-Colonna reaction, ${ }^{[50]}$ should also be mentioned. In addition the reinvestigation of the Hajos-Parrish-Eder-SauerWiechert reaction by List and Barbas in the late 90s opened an avenue for number of related transformations such as the enantioselective intermolecular cross-aldol reactions, as well as Mannich, Michael and Diels-Alder type transformations, and the application of these transformations in multistep (domino) reactions. ${ }^{[1,2,14]}$

\section{Catalysts}

As metals form easily Lewis acids, organic catalysts are more prone to form heteroatom-centered Lewis bases. Among them, $\mathrm{N}$ - and P-based catalysts are the most studied. Nucleophilic carbene catalysts are the third biggest class of catalysts to consider. Chiral amine catalysts are more easily available than phosphorous containing ones, due to the natural abundance. There are no natural P-containing chiral substrates for catalytic use: all of these catalysts are man-made. ${ }^{[51]}$ A particular advantage of phosphorous-based catalysts is the fact that in these compounds the reaction center and the asymmetric center are on the same atom. Moreover, the difference in Brønsted basicity of the phosphorous atom compared to the amine function may be advantageous to avoid base-mediated secondary reactions.

It is noteworthy that not only Lewis base, but also typical Lewis acid roles can be emulated by organocatalytic systems. The proton is arguably the most common Lewis acid found in the nature and exists in two forms classified by the nature of the hydrogen bond: polar covalent $(\mathrm{RX}-\mathrm{H})$ and polar ionic $\left(\mathrm{RX}^{+} \mathrm{H} . . . \mathrm{Y}^{-}\right)$. In the former case in asymmetric transformations the chiral information is dictated by the chiral anion while in the latter case the anion is non-chiral and the enantioselectivity is introduced 
by a chiral ligand, (usually an amine base) which complexes the proton.

Another class of activation is related to the particular reactivity of the nitrogen and discussed under the term aminocatalysis. ${ }^{[50]}$ Amine catalysts may give raise to either enamines and also imminium intermediates. ${ }^{[52]}$ The former activation results in increasing the electron density at the reaction center(s), the latter one corresponds to decreasing the electron density of the reaction center(s). A particularity of this type of chemistry is the facile equilibrium between these two, - electron rich and electron deficient - states (i.e. the acidbase form) of the same center (Scheme 7). It is easy to conceive this equilibrium simply by considering protonation-deprotonation, which on one hand may activate the reagent and, on other hand may contribute to the kinetic lability of the ligand. The particularity of this activation is the fact that, due to this equilibrium process, the same center may act as Lewis acid or Lewis base depending on the reaction conditions. While both intermediates are formed in the same mixture, the relative concentration of these structures is determined by the reaction conditions, leading to chemical transformations, which follow entirely different mechanistic paths, and results usually different products. More importantly, the same catalyst may promote the complementary nucleophile/ electrophile activation (i.e. promoting reactions via enamine and iminium intermediates, respectively) in the same reaction pot in a domino sequence. ${ }^{[53]}$

Another particular area of organic catalysis is the Lewis acid activation by a Lewis base. This catalysis is a powerful way to modulate the electron density of weakly electron withdrawing centers. ${ }^{[11]}$ Such interaction operates under well-defined circumstances between donor and acceptor entity, and results decreased electron density on the central atom in question.

Contrary to most organometallic catalysts, which achieve catalytic activity via a single (usually Lewis acid) function, ${ }^{[54]}$ most of the currently used efficient organocatalysts have more than one active centers. The vast majority of these catalysts are bifunctional catalysts, having commonly a Brønsted acid and Lewis base center. ${ }^{[17]}$ Such catalysts are able to activate both the donor and the acceptor, respectively, resulting in considerable rate acceleration, and also, increased selectivity due to the highly organized transition state. Moreover, the fact that reaction occurs in a confined reaction space, the catalyst acts as an 'entropy trap', in the sense originally proposed by Westheimer ("by overcoming the unfavorable entropy of activation usually inherent in a chemical reaction"). ${ }^{[55]}$ In the transition states hydrogen bond interactions constitute

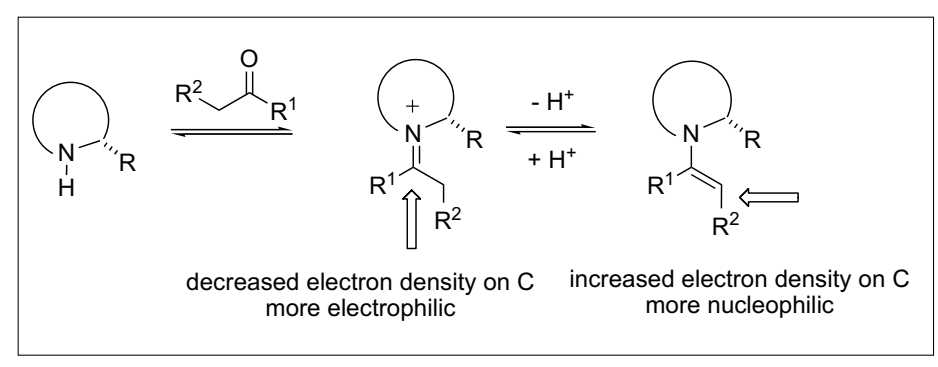

Scheme 7. The equilibrium between the iminium and enamine forms

a major driving force in the formation of specific molecular and complex geometries. Thus, protein and nucleic acid secondary and tertiary structural elements as well as many natural and artificial host-guest complexes are partly based on the directive power of intra- and intermolecular hydrogen bond formation. ${ }^{[56]}$ It is noteworthy that Brønsted acids may participate actively also in the chemical transformation: in many cases the chiral proton transfer determines both rate and selectivity of the global process.

\section{Reaction Types}

Organocatalytic reactions proceed usually either by a much 'tighter' or a much 'looser' transition structure than chiral metal complex mediated ones. The former class involves compounds which are acting as covalently (truly) bonded reagents. The bonding energy between the catalyst and substrate is higher than $15 \mathrm{kcal}$. The latter class includes reactions via noncovalent complexes, and usually via ion pairing as dominant interactions, and encompasses interactions lower than $4 \mathrm{kcal} / \mathrm{mol} .^{[2]}$

\section{Covalent Catalysis}

The vast majority of organocatalytic reactions proceeds via covalent formation of a catalyst-substrate adduct to form an activated complex. ${ }^{[5]}$ Amine-based reactions are typical examples, in which amino acids, peptides, alkaloids and synthetic nitrogen-containing molecules are used as chiral catalysts. The main body of reactions includes reactions of the so-called generalized enamine cycle and charge accelerated reactions via the formation of iminium intermediates. Also, Morita-Baylis Hillman reactions, oxidation with the in situ generation of chiral dioxirane catalysts, asymmetric ylide reactions such as epoxidation, cyclopropanation, and aziridination, etc. belong to this class of reactions.

\section{Noncovalent Organocatalysis}

There are a growing number of asymmetric organocatalytic reactions which are accelerated by weak interactions. This type of catalysis includes neutral host-guest complexation or acid/base associations be- tween catalyst and substrate. The former case is highly reminiscent to the way that many enzymes effect reactions, by bringing together reactants in an active site without the formation of covalent bonds.

Weak acid-base chiral complex formation represents hydrogen bond catalysis and deprotonation followed by cation-anion association under homogenous, and also under phase-transfer conditions. ${ }^{[12,57]}$

\section{Perspectives}

After a prolific decade of organocatalytic transformations, the question arises about the use of these reactions in multistep synthesis. Undoubtedly there is a gap between the number of proposed novel methods and the number of applications in synthesis that has appeared to date relying on these methods. A major problem encountered is the substrate dependency and the relatively narrow scope of these transformations. Can these factors be ameliorated, or should the often-noticed lack of generality be considered as an inherent characteristic of these transformations? Or, ultimately, should our well-rehearsed preparative reflexes which consider chemical reactions as "chemical operators' be reconsidered and adapted to the novel conditions in devising novel synthetic schemes? One possible explanation of the observed limitations may be related to our incomplete mechanistic understanding of these transformations. Despite important progress our understanding of the basic factors that control reactivity and selectivity is only partial, if not puzzling. That is the case, for example, with the presence of water. Most of the reactions not only tolerate water but a small amount of water is even beneficial for the reactivity and selectivity. ${ }^{[58]}$

I agree with many chemists who consider that in organocatalysis there remain many interesting and useful things to do.

Received: March 26, 2007

[1] a) A. Berkessel, H. Gröger, 'Asymmetric Organocatalysis, From Biomimetic Concepts to Applications in Asymmetric Synthesis', Wiley-VCH, Weinheim, 2005; b) 
'Enantioselective Organocatalysis, Reactions and Experimental Procedures', Ed. P I. Dalko, Wiley-VCH, Weinheim, 2007.

[2] General reviews on asymmetric organocatalysis: a) P. I. Dalko, L. Moisan, Angew. Chem., Int. Ed. 2001, 40, 3726; b) P. I. Dalko, in 'The McGraw-Hill 2003 Yearbook', McGraw-Hill, New York, 2003, p 312; c) P. I. Dalko, L. Moisan, Angew. Chem., Int. Ed. 2004, 43, 5138; d) H. F. Jiang, Y. G. Wang, H. L. Liu, et al. Chin. J. Org. Chem. 2004, 24, 1513; e) P. I. Dalko, L. Moisan, Angew. Chem. Sonderausgabe $2005 \mathbf{2 0 0 5}$, A147; f) Y. Hayashi, J. Synth. Org. Chem. Jpn. 2005, 63, 464; g) M. J. Gaunt, C. C. C. Johnsson, A. McNally, N. T. Vo, Drug Discovery Today 2007, 12, 8

[3] Special issues on asymmetric organocatalysis: Eds. B. List, C. Bolm, Adv. Synth. Catal. 2004, 346, 1007; Eds. K. N. Houk, B. List, Acc. Chem. Res. 2004, 37, 487.

[4] Reviews on organometallic/organocatalitic interface: a) B. Plietker, Angew. Chem., Int. Ed. 2006, 45, 190; b) P. Kocovsky, A. V. Malkov, Russ. Chem. Bull. 2004, 53, 1806. See also c) G. C. Fu, Acc. Chem. Res. 2006, 39, 853.

[5] Aminocatalysis: a) B. List, Chem. Commun. 2006, 819; b) G. Lelais, D. W. C. MacMillan, Aldrichimica Acta 2006, 39 , 79; c) M. Marigo, K. A. Jørgensen, Chem. Commun. 2006, 2001; d) J. Seayad, B. List, Org. Biomol. Chem. 2005, 3, 719; e) A. J. A. Cobb, D. M. Shaw, D. A. Longbottom, J. B. Gold S. V. Ley, Org. Biomol. Chem. 2005, 3, 84; f) X. F. Wei, Chin. J. Org. Chem. 2005, 25, 1619; g) S. B. Tsogoeva, Lett. Org. Chem. 2005, 2, 208; h) B. List, Acc. Chem. Res. 2004, 37, 548; i) C. Allemann, R. Gordillo, F. R. Clemente, P. H.-Y. Cheong, K. N. Houk, Acc. Chem. Res. 2004, 37, 558; j) S. France, D. J. Guerin, S. J. Miller, T. Lectka, Chem. Rev. 2003, 103, 2985; k) B. List, Tetrahedron 2002, 58, 5572; 1) M. Movassaghi, E. N. Jacobsen, Science 2002, 298, 1904; m) E. R. Jarvo, S. J. Miller, Tetrahedron 2002, 58, 2481; n) H. Gröger, J. Wilken, Angew. Chem., Int. Ed. 2001, 40, 529; o) B. List, Synlett 2001, 1675.

[6] Morita-Baylis-Hillman reactions: a) K. Y. Lee, S. Gowrisankar, J. N. Kim, Bull. Korean Chem. Soc. 2005, 26, 1481; b) D. Basavaiah, A. J. Rao, T. Satyanarayana, Chem. Rev. 2003, 103, 811; c) P. Langer, Angew. Chem., Int. Ed. 2000, 39, 3049.

[7] Asymmetric catalysis by chiral hydrogen-bond donors: a) T. Akiyama, J. Itoh, K. Fuchibe, Adv. Synth. Catal. 2006, 348 , 999; b) M. S. Taylor, E. N. Jacobsen, Angew. Chem., Int. Ed. 2006, 45, 1520; c) C. Bolm, T. Rantanen, I. Schiffers, L. Zani, Angew. Chem., Int. Ed. 2005, 44 , 1758; d) H. Yamamoto, K. Futatsugi, Angew. Chem., Int. Ed. 2005, 44, 1924; e) C. A. Hunter, Angew. Chem., Int. Ed. 2004, 43, 5310; f) P. M. Pihko, Angew. Chem., Int. Ed. 2004, 43, 2062; g) M.
Oestreich, Nachr. Chem. 2004, 52, 35; h) P. R. Schreiner, Chem. Soc. Rev. 2003, 32, 289; i) S. J. Connon, Chem Eur. J. 2006, 12, 5419; j) Y. Takemoto, Org. Biomol. Chem. 2005, 3, 4299.

[8] Asymmetric acylation: a) E. Vedejs, M. Jure, Angew. Chem., Int. Ed. 2005, 44, 3974; b) D. E. J. E. Robinson, S. D. Bull, Tetrahedron: Asymm. 2003, 14, 1407; c) J. R. Dehli, V. Gotor, Chem. Soc. Rev. 2002, 31, 365; d) F. F. Huerta, A. B. E. Minidis, J.-E. Bäckvall, Chem. Soc. Rev. 2001, 30, 321; e) J. Eames, Angew. Chem., Int. Ed. 2000, 39, 885.

[9] Reactions via carbenes: D. Enders, T. Balensiefer, Acc. Chem. Res. 2004, 37, 534.

[10] Oxidations: a) A. K. Yudin, 'Aziridines and Epoxides in Organic Synthesis', Wiley-VCH: Weinheim, 2006; b) E. M. McGarrigle, D. G. Gilheany, Chem. Rev. 2005, 105, 1563; c) Q.-H. Xia, H.-Q. Ge, C.-P. Ye, Z.-M. Liu, K.-X. Su, Chem. Rev. 2005, 105, 1603; d) Y. Shi, Acc. Chem. Res. 2004, 37, 488; e) D. Yang, Acc. Chem. Res. 2004, 37, 497; f) W. Adam, C. R. Saha-Moller, P. A. Ganeshpure, Chem. Rev. 2001, 101, 3499.

[11] Lewis base-catalyzed transformations: a) S. E. Denmark, J. Fu, Chem. Commun. 2003, 167; b) S. E. Denmark, J. Fu, Chem. Rev. 2003, 103, 2763; c) J. W. J. Kennedy, D. G. Hall, Angew. Chem., Int. Ed. 2003, 42, 4732; (d) S. E. Denmark, R. A. Stavenger, Acc. Chem. Res. 2000, 33, 432.

[12] Asymmetric phase transfer reactions: a) B. Lygo, B. I. Andrews, Acc. Chem. Res. 2004, 37, 518; b) K. Maruoka, T. Ooi, Chem. Rev. 2003, 103, 3013; b) C. Najera, Synlett 2002, 1388; c) M. J. O'Donnell, Aldrichimica Acta 2001, 34, 3.

[13] Asymmetric shape and site selective organocatalytic reactions: a) 'Artificial Enzymes', Ed. R. Breslow, Wiley-VCH, Weinheim, 2005; b) C. W. Lim, B. J. Ravoo, D. N. Reinhoudt, Chem. Commun. 2005, 5627; c) C. Alexander, L. Davidson, W. Hayes, Tetrahedron 2003, 59, 2025; d) G. Wulff, Chem. Rev. 2002, 102, 1; e) B. Clapham, T. S. Reger, K. D. Janda, Tetrahedron 2001, 57, 4637; f) B. Sellergren, Angew. Chem., Int. Ed. 2000, 39, 1031.

[14] a) J. Seayad, B. List, 'Catalytic Asymmetric Multi-Component Reactions', in 'Multi-Component Reactions', Eds. J. Zhu, H. Bienayme, Wiley-VCH, Weinhein, 2004; b) J.-C. Wasilike, S. J. Obrey, R. T. Baker, G. C. Bazan, Chem. Rev. 2005, 105, 1001; c) D. J. Ramon, M. Yus, Angew. Chem., Int. Ed. 2005, 44, 1602; d) D. B. Ramachary, M. Kishor, G. B. Reddy, Org. Biomol. Chem. 2006, 4, 1641; e) H-C. Guo, J-A. Ma, Angew. Chem., Int. Ed. 2006, 45, 354; (f) H. Pellissier, Tetrahedron 2006, 62, 1619; g) H. Pellissier, Tetrahedron 2006, 62, 2143; h) H.-C. Guo, J.-A. Ma, Angew. Chem., Int. Ed. 2006, 45, 354; i) L. F. Tietze, G. Brasche, K. M. Gericke, 'Domino
Reactions in Organic Synthesis', Wiley$\mathrm{VCH}$, Weinheim, 2006 and references; j) D. Enders, C. Grondal, M. R. M. Huttl, Angew. Chem., Int. Ed. 2007, 46, 1570; k) A. Carlone, S. Cabrera, M. Marigo, K. A. Jørgensen, Angew. Chem. Int. Ed. 2007, $46,1101$.

[15] a) H. Bernard, G. Bulow, U. E. W. Lange, H. Mack, T. Pfeiffer, B. Schäfer, W. Seitz, T. Zierke, Synthesis 2004, 2367; b) M. Breuer, K. Ditrich, T. Habicher, B. Hauer, M. Kesseler, R. Sturmer, T. Zelinski, Angew. Chem., Int. Ed. 2004, 43, 788; c) H. Tye, P. J. Comina, J. Chem. Soc., Perkin 1 2001, 1729; d) H. J. Federsel, Nature Rev. Drug Discovery 2005, 4, 685; e) H. U. Blaser, B. Pugin, F. Spindler, J. Mol. Catal., Chemical 2005, 231, 1.

[16] C. Thirsk, D. Jay, Chem. Ind. 2004, 16, 15.

[17] S. Pizzarello, A. L. Weber, Science 2004, 303, 1151.

[18] G. M. M. Caro, U. J. Meierhenrich, W. A. Schutte, B. Barbier, A. A. Segovia, H. Rosenbauer, W. H.-P. Thiemann, A. Brack, J. M. Greenberg, Nature 2002, 416, 403.

[19] a) M.Klussmann, H. Iwamura, S.P. Mathew, D. H. Wells, Jr., U. Pandya, A. Armstrong, D. G. Blackmond, Nature 2006, 441, 621; b) Y. Hayashi, M. Matsuzawa, J. Yamaguchi, S. Yonehara, Y. Matsumoto, M. Shoji, D. Hashizume, H. Koshino, Angew. Chem., Int. Ed. 2006, 45, 4593; c) A. B. Northrup, D. W. C. MacMillan, Science 2005, 305, 1752; d) A. Córdova, M. Engqvist, I. Ibrahem, J. Casas, H. Sunden, Cheminform 2005, 36, 32; e) A. Córdova, I. Ibrahem, J. Casas, H. Sundén, M. Engqvist, E. Reyes, Chem. Eur. J. 2005, 11, 4772; f) A. Córdova, M. Engqvist, I. Ibrahem, J. Casas H. Sundén, Chem. Commun. 2005, 2047; g) U. Kazmaier, Angew. Chem., Int. Ed. 2005, 44, 2186; h) See also: G. Carrea, S. Colonna, D. R. Kelly, A. Lazcano, G. Ottolina S. M. Roberts, Trends Biotechnol. 2005, 23, 507.

[20] a) G. F. Joyce, G. M. Visser, C. A. A. van Boeckel, J. H. van Boom, L. E. Orgel, J. van Westerenen, Nature 1984, 310, 602; b) M. Bolli, R. Micura, A. Eschenmoser, Chem. Biol. 1997, 4, 309.

[21] K. Tamura, P. Schimmel, Science 2004, $305,1253$.

[22] H. B. Kagan in 'Comprehensive Asymmetric Catalysis', Eds. E. N. Jacobsen, A. Pfaltz, H. Yamamoto, Springer: Berlin, 1999, Vol 1, 101.

[23] G. Bredig, R. W. Balcom, Ber. Deutsch. Chem. Ger. 1908, 41, 740.

[24] G. Bredig, K. Fajans, Ber. Deutsch. Chem. Ger. 1908, 41, 752.

[25] L. Rosentahler, Biochem. Z. 1908, 14, 232.

[26] G. Bredig, P. S. Fiske, Biochem. Z. 1912, 46,7 .

[27] M. M. Vavon, P. Peignier, Bull. Soc. Fr. 1929, 45, 293.

[28] R. Wegler, Liebigs Ann. Chem. 1932, 498, 62 
[29] See in W. Langenbeck, 'Die Organische Katalysatoren und ihre Beziehungen zu den Fermenten' 2. Aufl. Springer, Berlin, 1949; b) W. Langenbeck, 'Fortschritte der Chemischen Forschung', Vol. 6, Springer, Berlin, 1966, p 301; see also in c) B. Lukowczyk, J. Pract. Chem. 1959, 8, 372.

[30] H. D. Dakin, J. Biol. Chem. 1909, 7, 49.

[31] V. Prelog, M. Wilhelm, Helv. Chim. Acta 1954, 37, 1634.

[32] H. Pracejus, Justus Liebigs Ann. Chem. 1960, 634, 9 .

[33] B. Långström, G. Bergson, Acta Chem. Scand. 1973, 27, 3118.

[34] For a review see: H. Wynberg, Top. Stereochem. 1986, 16, 87.

[35] Z. G. Hajos, D. R. Parrish, J. Org. Chem. 1974, 39, 1615.

[36] U. Eder, G. Sauer, R. Wiechert, Angew. Chem. Int. Ed. Engl. 1971, 10, 496.

[37] See for example: S. J. Danishefsky, J. J. Masters, W. B. Young, J. T. Link, L. B. Snyder, T. V. Magee, D. K. Jung, R. C. A. Isaacs, W. G. Bornmann, C. A. Alaimo, C. A. Coburn, M. J. Di Grandi, J. Am. Chem. Soc. 1996, 118, 2843.

[38] G. Stork, R. Terrell, J. Szmuszkovicz, J. Am. Chem. Soc. 1954, 76, 2029.

[39] For a pioneering review see: J. Martens, Top. Curr. Chem. 1984, 125, 165.

[40] N. Cohen, Acc. Chem. Res. 1976, 9, 412.

[41] T. P. Brady, S. H. Kim, K. Wen, E. A. Theodorakis, Angew. Chem., Int. Ed. 2004, 43, 739 and references cited.

[42] a) R. B. Woodward, E. Logusch, K. P. Nambiar, K. Sakan, D. E. Ward, B.-W. Au-Yeung, P. Balaram, L. J. Browne, P. J. Card, C. H. Chen, R. B. Chènevert, A. Fliri, K. Frobel, H.-J. Gais, D. G. Garratt, K. Hayakawa, W. Heggie, D. P. Hesson, D. Hoppe, I. Hoppe, J. A. Hyatt, D. Ikeda, P. A. Jacobi, K. S. Kim, Y. Kobuke, K. Kojima, K. Krowicki, V. J. Lee, T. Leutert, S. Malchenko, J. Martens, R. S. Matthews, B. S. Ong, J. B. Press, T. V. Rajan Babu, G. Rousseau, H. M. Sauter, M. Suzuki, K. Tatsuta, L. M. Tolbert, E. A. Truesdale, I. Uchida, Y. Ueda, T. Uyehara, A. T. Vasella, W. C. Vladuchick, P. A. Wade, R. M. Williams, H. N.-C. Wong, J. Am. Chem. Soc. 1981, 103, 3210; b) S. Takano, C. Kasahara, K. Ogasawara, Chem. Commun. 1981, 635.

[43] A. Mori, S. Inoue, in 'Comprehensive Asymmetric Catalysis', Eds. E. N. Jacobsen, A. Pfalz, H. Yamamoto, Springer, Heidelberg, 1999, pp 983-994 and references.

[44] M. S. Iyer, K. M. Gigstad, N. D. Namdev, M. Lipton, J. Am. Chem. Soc. 1996, 118, 4910.

[45] M. S. Sigman, E. N. Jacobsen, J. Am. Chem. Soc. 1998, 120, 4901.

[46] a) U.-H. Dolling, P. Davis, E. J. J. Grabowski, J. Am. Chem. Soc. 1987, 106, 446; b)
D. L. Hughes, U.-H. Dolling, K. M. Ryan, E. F. Schoenewaldt, E. J. J. Grabowski, J. Org. Chem. 1987, 52, 4745.

[47] M. J. O’Donnell, W. D. Bennett, S. Wu, J. Am. Chem. Soc. 1989, 111, 2353.

[48] M. J. O'Donnell, S. Wu, J. C. Huffman, Tetrahedron 1994, 50, 4507.

[49] For a review on catalytic Diels-Alder reactions see: a) H. B. Kagan, O. Riant, Chem. Rev. 1992, 92, 1007.

[50] a) S. Juliá, J. Masana, J. C. Vega, Angew. Chem., Int. Ed. Engl. 1980, 19, 929; b) S. Juliá, J. Guixer, J. Masana, J. Rocas, S. Colonna, R. Annuziata, H. Molinari, $J$. Chem. Soc., Perkin Trans. 1 1982, 1317. For mechanistic discussion of this reaction see: c) A. Berkessel, N. Gasch, K. Glaubitz, C. Koch, Org. Lett. 2001, 3, 3839.

[51] For a review on phosphines see: J. L. Methot, W. R. Roush, Adv. Synth. Catal. 2004, 346, 1035.

[52] As defined in ref. [5i]: "There are two aminocatalytic pathways. Iminium catalysis directly utilizes the higher reactivity of the iminium ion in comparison to the carbonyl species and facilitates Knoevenagel-type condensations, cyclo- and nucleophilic additions, and cleavage of $\sigma$-bonds adjacent to the $\alpha$-carbon. Enamine catalysis on the other hand involves catalytically generated enamine intermediates that are formed via deprotonation of an iminium ion, and react with various electrophiles or undergo pericyclic reactions."

[53] a) J. W. Yang, M. T. Hechavarria Fonseca, B. List, J. Am. Chem. Soc. 2005, 127, 15036; b) Y. Huang, A. Walji, C. H. Larsen, D. W. C. MacMillan, J. Am. Chem. Soc. 2005, 127, 15051.

[54] For reviews on bifunctional catalysts: a) M. Shibasaki, H. Sasai, Angew. Chem., Int. Ed. Engl. 1997, 36, 1236; b) H. Gröger, Chem. Eur. J. 2001, 7, 5246-5251; c) G. J. Rawlands, Tetrahedron 2001, 57, 1865; d) M. Shibasaki, N. Yoshikawa, Chem. Rev. 2002, 102, 2187-2209; e) J.-A. Ma, D. Cahard, Angew. Chem., Int. Ed. 2004, 43, 4566; f) M. Kanai, N. Kato, E. Ichikawa, M. Shibasaki, Synlett 2005, 10, 1491.

[55] a) F. H. Westheimer, Adv. Enzymol. 1962, 24, 441; b) F. H. Westheimer, Adv. Phys. Org. Chem. 1985, 21, 1.

[56] a) G. A. Jeffrey, W. Saenger, 'Hydrogen Bonding in Biological Structures', Springer, Berlin, 1994; b) D. G. Lonergan, G. Deslongchamps, S. Tomás, Tetrahedron Lett. 1998, 39, 7861.

[57] M. Makosza, M. Fedorynski, Catal. Rev. Sci. Eng. 2003, 45, 321.

[58] a) A. P. Brogan, T. J. Dickerson, K. D. Janda, Angew. Chem., Int. Ed. 2006, 45, 8100; b) Y. Hayashi, Angew. Chem., Int. Ed. 2006, 45, 8103 . 